\title{
A Comprehensive Analysis and A Case Study on the Intensity of Different Types of Crimes Committed Against Women Living in Delhi and Ner: Post Nirbhaya
}

\author{
Arvind Kumar Pal and Ramendra Nath Verma \\ ${ }^{1}$ School of Media Film Et Entertainment (SMFE), Department of \\ Mass Communication, Sharda University, Greater Noida \\ ${ }^{2}$ Ph.D Research Scholar, School of Media Film \& Entertainment (SMFE), \\ Department of Mass Communication, Sharda University, Greater Noida
}

\section{ABSTRACT}

The cases of rape and other crimes committed against women are reported in media every day. The fatal gang rape of a 23 year old woman on a moving bus in the National capital of India captured media headlines not only in India but across the world due to the horrific manner in which this crime was committed. The present research attempts to understand the representation of crime against women in print media with special reference to Delhi gang rape case and also how the young Indian women feels about such representation of incidences in media. The data is collected from two newspapers, The Times of India and Amar Ujala published from Delhi from the first reporting of case till date. All the news items were read and re-read carefully and analyzed thematically. The primary data was also collected among the 100 young female students studying in Sharda University to know about their views regarding the portrayal of crime against women in Indian print media with special reference to Delhi gang rape case. Dhananjay Chatterjee was the last convict who was hanged in year 2004 for rape in Calcutta. From that time till date more than four lakhs rape cases has been reported in all over India in different police station. The Nirbhaya rape case is in final stage of hearings and we hope that culprits will be hanged soon. It can be concluded that media needs to be more sensitive towards coverage of crime against women and general public needs to be more vocal and aware to deal with these cases in more effective manner.

KEY WORDS: WOMEN; CRIME; RAPE, PRINT MEDIA.

\section{INTRODUCTION}

Rape is an unlawful sexual intercourse with a woman without her consent. It is a cross-cultural crime stemming primarily from patriarchal ideologies and gender power. It is generally used as an instrument of communication

\section{ARTICLE INFORMATION}

Received 12th Oct 2020 Accepted after revision 26th Dec 2020 Print ISSN: 0974-6455 Online ISSN: 2321-4007 CODEN: BBRCBA

Thomson Reuters ISI Web of Science Clarivate Analytics USA and Crossref Indexed Journal

\section{Clarivate
Analytics}

NAAS Journal Score 2020 (4.31)

A Society of Science and Nature Publication,

Bhopal India 2020. All rights reserved.

Online Contents Available at: http//www.bbrc.in/

Doi: http://dx.doi.org/10.21786/bbrc/13.15/43 about masculinity and powerfulness. The cases of rape and other crimes committed against women are reported in print media every day. A number of researchers have attempted to understand the portrayal of crime against women in print media. There are a number of myths related to rape in the print media .These include: rape is sex, the assailant is motivated by lust, the assailant is perverted or crazy, the assailant is usually lower class, women provoke rape, women deserve rape, only 'loose' women are victimized, a sexual attack sullies the victim, rape is punishment for past deeds and women cry rape for revenge.

The media can also play role of an activist and can generate a public opinion about the sensitive issues such as rape.The fatal gang rape of a 23 year old woman on

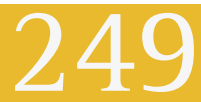


a moving bus in the National capital of India captured media headlines not only in India but across the world due to the horrific manner in which this crime was committed. The present research paper attempts to understand the representation of crime against women in Indian print media with special reference to Delhi gang rape case and also how the young Indian women feels about representation of such incidences in media. The present study highlighted the gender bias in the use of language for rape.

\section{Objective}

1. To study changing trends in the quantum of crimes committed against women in India.

2. To identify shifting trends in the nature of crimes committed against women in India.

\section{Hypothesis To Be Tested}

1. There are significant changing trends in the quantum of crimes committed against women in India.

2. There are significant shifting trends in the nature of crimes perpetrated on women in India.

\section{METHODOLOGY}

A key aspect of coding is its reliability. There are two forms of coding reliability, both of which are important. The first is intra-coder reliability. To deal with first kind of reliability, the data was observed again and again over a period of time to gain a deeper insight, and to arrive at the common themes. The second form of reliability is inter-coder reliability. This form of reliability was taken care of by taking help of researchers involved in similar kind of research. The themes which were commonly agreed upon are included in the present study.

Analysis and Findings: A sample size of 100 respondents mainly girls studying in Sharda University was taken up for the collection of primary data. The theme such as 'the rape', 'the victim', 'the protest', 'the after affect and 'the verdict' emerged which are discussed in detail. The secondary data was taken up from Delhi Police website.

The Rape: In media, the Delhi gang rape incident was referred as 'capital gang rape' and 'Delhi shame' in Hindustan Times, and 'capital shame' and 'the Delhi gang rape' in The Times of India. It has been described as a 'ghastly incident', 'brutal violence', 'spine chilling incident', 'scar for life', 'shocking incident', 'matter of shame', 'aggravated sexual assault', 'brazen incidence', 'rarest of rare case', and 'unfortunate'. Rape is mentioned as a 'problem that has plagued all metropolitan cities'.

The titles such as 'Delhi rape horror' (19 December, 2012, The Times of India) appeared and the related issues such as security of women in the titles such as 'ensure sense of security' (23 December, 2012, Hindustan Times). With the background that Delhi gang rape was widely covered by the print media, the respondents were asked to define rape. The most common definition of rape appeared to be: "sexual assault with a person against his/her will". While some respondents only mentioned the physical dimension of rape but others also mentioned about psycho-social dimensions of rape such as mental harassment, social stigma and abetment to suicide. Some respondents mentioned the seriousness of the issue and stressed upon the need for a serious action against the rapists. A respondent mentioned that "rape is worse than terrorism and destructs the social life of the victim".

The Victim: By looking at the coverage of Delhi gang rape, the one obvious question that appears in one's mind is: why this particular case gained importance in the mass media? The answer to this question can be derived from what we call as 'media selectivity' and the 'dramatic value' of a crime. As Delhi gang rape case has repeatedly been called as a 'rarest of the rare case' due to the horrific nature of the crime. In order to know how rapes are portrayed in Indian media, around 100 respondents were asked whether the media treat rape cases sensitively or sensationalize them. Except 20 respondents all other believed that media sensationalize the rape cases if it happens in Delhi and NCR. Most of them believed that a large number of rapes are happening in India and these often go unnoticed. Only a few are covered which creates hype for few days but later the issue of justice is lost.

Except 20 respondents, all other felt that media sensationalize the rape cases for various reasons which include desire for popularity, lack of sensitive training to deal with such issues and lack of concern for one who is raped. One of the respondents narrated, "media uses someone's suffering as a stepping stone to popularise their newspapers and channels". The 20 respondents who believed that media treats rape cases sensitively, argued that media creates awareness regarding sexual violence which is important to deal with such cases. One of the most important issues in rape coverage in media is anonymity.

Due to the stigma associated with rape, the identity of women raped is often not disclosed. Similar findings were made in the present study. Except 10 respondents all other believed that due to the stigma attached to rape and ways in which our society views rape victims and their families, the identity of one who is raped should not be disclosed. On contrary, one respondent narrated, "rape is not a matter of shame for the victim but for the rapist. Shout for justice and tell the identity proudly". Another respondent mentioned, "it should actually be left upto the victim and her family to decide".

In order to hide the identity of the Delhi gang rape victim, the names such as 'Nirbhaya' (fearless), 'Amanat' (treasure), 'Damini' (lightening) and 'Jagriti' (awareness) were used in the print media. The girl has been repeatedly referred to as 'gang rape victim' (27 December, 2012, Nav Bharat Times) and 'women in distress' (25 December, 2012,Hindustan). The respondents in the present study were asked whether the fictitious names should be used for those raped and does it provide any help. Except twenty respondents, all believed that such names do not 
provide any kind of help. A respondent narrated, "when a person's name is unknown to the people, use of fictitious names help to address the victim". Another respondent mentioned, "the society use these names just as pronoun so that the victim can be specified". Yet another argued, "providing fictitious names gives confidence to the women or girl who are rape victims".

The Protest: The Delhi gang rape was followed by the violent protests in Delhi at Indian Gate, Jantar Mantar, Ramlila Maidan, Vijay Chowk and Rashtrapati Bhawan. These protests have been mentioned as a reaction of 'utter shock and anguish' which is 'justified'. At some places, these protests have been referred to as violent, 'goondaraj' (hooliganism) and 'vandalism', and the protestors as 'hooligans'. A number of remarks made by various politicians and others against the victim and the protestors were presented by print media. Certain Khappanchayats (local community councils) of Haryana issued a decree banning women from carrying cell phones and wearing jeans or any other clothing that might "invite trouble.

In order to know about how the young Indian women feel about the 'blame debate' that was widely covered by print media, all the respondents believed that women are not responsible for rape. They mentioned a number of causes of rape which include male patriarchy, western influences, stereotype of society, access to pornographic videos, drug abuse, alcoholism, lack of education particularly sex education, treatment of women as sex objects, weak judiciary and fearlessness of laws.

The After-Effect and the Verdict: This incidence generated a lot of debate regarding the strengthening of rape laws in India. The respondents were asked about the role of police and judiciary in dealing with rape cases. The respondents suggested that speedy justice should be provided in rape cases by fast track courts and strict punishment should be given to culprits. Some others highlighted that police and judiciary should be sensitive to those who are raped and their families so that "victims are not victimised' and mentioned that they should not be unduly harassed in the process. One of the respondents called Indian judiciary as 'slow churning machinery'.

Film India's Daughter By Leslee Udwin Post Nirbhaya: INDIA's DAUGHTER is the story of the short life, and brutal gang rape and murder in Delhi on 16th December 2012 of an exceptional and inspiring young woman. The rape of the 23 year old medical student by 6 men on a moving bus, and her death, sparked unprecedented protests and riots throughout India and led to the first glimmers of a change of mindset. Interwoven into the story line are the lives, values and mindsets of the rapists whom the film makers have had exclusive and unprecedented access to interview before they hang. The film examines the society and values which spawn such violent acts, and makes an optimistic and impassioned plea for change.
The film was scheduled to be aired on TV channels round the world on March 8, 2015 to coincide with International Women's Day. However, when excerpts of the film, which included an interview with Mukesh Singh, one of the four men convicted of the rape and murder, were broadcast, a court stay order prohibiting the broadcast was obtained by the Indian police. The BBC complied with the request and did not air the film in India. Yet it aired outside of India on 4 March, was uploaded on You Tube, and soon went viral via shares on social media. On 5 March, the Indian government directed YouTube to block the video in India.

Litrature Review: Chandan Mukherjee, Preet Rustagi and N. Krishnaji (2001), "Crimes against Women in India: Analysis of Official Statistics" Economic and Political Weekly, Vol. 36, No. 43 (Oct. 27 - Nov. 2, 2001), pp. 40704080. They attempt to see what official, published data reveal, whether there are clear-cut regional patterns and if so whether they can lead to meaningful hypotheses for future work. There are some significant researches being conducted by scholars in finding important factors influencing reporting behavior of victims of violence.

Kaveri Devi Mishra, Sridhar Krishnaswami, Citizens Journalism in India: A Case Study of Delhi, Journal of Education \& Social Policy Vol. 1 No. 1; June 2014. Their paper evaluates and analyzes the emergence, trend, and role of Citizen Journalism with explicit reference to Delhi Gang rape - Nirbhaya case in 2012. The paper at the end raises concerns on the ethics and to what extent unfiltered information can reach the masses and strike a balance in the society. Kriti Singh, A Small Study On Impact Of Crime Against Women News Stories On Indian Urban, Imperial Journal of Interdisciplinary Research, Vol-2, Issue-3, 2016 The research paper is an attempt to gauge the impact of crime news stories related to women on urban women based in urban areas of India. The paper tries to analyze the crime news consumption habits in urban women and what impact does these news stories create in the mind of women. Jason Burke, The problem with crime against women in Delhi, Vol-1 Issue-2, 2017.

Since 2012 when the Nirbhaya gang rape happened, there was a marked increase in the registration of cases relating to crimes against women across the country. A total number of 24,923 rapes were reported in 2012, this figure rose up to 33,707 in 2013, due to increase in awareness among the common people and prompt registration of FIRs by police on complaints of women. The number of rape cases again rose up to 36,735 in 2014 out of which 2346 were gang-rapes. However, the numbers came down to 34,561 in 2015 including 2,113 gang rapes. Radha and P. Govindaraju (2016) News media shapes our opinions and beliefs on issues of social importance. Especially, when it comes to issues relating to violence against women there are several studies on the discourse of the news media. This paper tries to explore the reception of news on issues relating to violence against women and if framing of such news has any influence on the news reception. 
Joseph (2004) states "the manners in which such crimes are reported render them so ordinary, mundane and predictable a feature of daily life that they barely enter readers' consciousness, let alone impinges on their conscience". Looking further a trend of victim blaming existing where the reports try to find out what role the victim had in the crime to happen. Maham Abbasi, 2020 Crime against women in India has become an eminent topic of discussion in recent years and the issue has been brought to the foreground for concern due to the increasing trends in crimes performed against women. Most of the crimes get reported and a massive dataset is being generated every year. Analysing the crime reports can help the law enforcement section to take preventive measures for reducing the crime, but processing this voluminous data is strenuous and error-prone. So application of various text mining techniques can be of great help for visualising the crime trend.

Patowary (2014) Media's role towards women is becoming the growing concern of the feminist writers, basically regarding participation, performance and portrayal of women. Schildkraut (2017) Crime news is an abundant staple in modern media coverage. Nowhere is this more evident than in the newspaper medium, which often faces fewer constraints with respect to space and time compared to other formats (e.g., television), thereby enabling more stories to be generated. Reetinder Kaur (2013) The cases of rape and other crimes committed against women are reported in media every day. The fatal gang rape of a 23 year old woman on a moving bus in the National capital of India captured media headlines not only in India but across the world due to the horrific manner in which this crime was committed. The present research paper attempts to understand the representation of crime against women in print media with special reference to Delhi gang rape case and also how the young Indian women feels about representation of such incidences in media.

Justice Js Verma Committee Report: This committee was constituted to recommend amendments to the Criminal Law so as to provide for quicker trial and enhanced punishment for criminals accused of committing sexual assault against women. The committee submitted its report on 23 January 2013.

\begin{tabular}{|c|c|c|c|c|c|c|c|c|c|}
\hline $\begin{array}{l}\text { Crime } \\
\text { Head }\end{array}$ & 2012 & 2013 & 2014 & 2015 & 2016 & 2017 & 2018 & $\begin{array}{l}2018 \\
\text { UPTO }\end{array}$ & $\begin{array}{l}2019 \\
15 T H \\
\text { NOV. }\end{array}$ \\
\hline $\begin{array}{l}\text { Rape(376 Ipc) } \\
\text { Assault On Women }\end{array}$ & 706 & 1636 & 2166 & 2199 & 2155 & 2146 & 2135 & 1921 & 1947 \\
\hline $\begin{array}{l}\text { With Intent To } \\
\text { Outrage Her } \\
\text { Modesty ( } 354 \text { Ipc) } \\
\text { Insult To The }\end{array}$ & 727 & 3515 & 4322 & 5367 & 4165 & 3422 & 3314 & 2956 & 2616 \\
\hline $\begin{array}{l}\text { Modesty Of Women } \\
\text { (509 Ipc) }\end{array}$ & 214 & 916 & 1361 & 1492 & 918 & 640 & 599 & 544 & 427 \\
\hline Kidnapping Of Women & 2048 & 3286 & 3604 & 3738 & 3445 & 3439 & 3482 & 3067 & 3104 \\
\hline $\begin{array}{l}\text { Abduction Of Women } \\
\text { 498-A/406 Ipc }\end{array}$ & 162 & 323 & 423 & 556 & 444 & 322 & 262 & 240 & 170 \\
\hline $\begin{array}{l}\text { (Cruelty By Husband } \\
\text { And In Laws) }\end{array}$ & 2046 & 3045 & 3194 & 3536 & 3877 & 2745 & 3416 & 2716 & 3187 \\
\hline Dowry Death (304b) & 134 & 144 & 153 & 122 & 162 & 120 & 153 & 133 & 106 \\
\hline $\begin{array}{l}\text { Dowry Prohibition } \\
\text { Act }\end{array}$ & 15 & 15 & 13 & 20 & 18 & 11 & 15 & 14 & 16 \\
\hline
\end{tabular}

Table 2. Data Analysis Based On Delhi Police Inputs (2012-2019) Rape (376 IPC)

\begin{tabular}{|l|c|c|c|c|c|c|c|c|}
\hline YEARS & 2012 & 2013 & 2014 & 2015 & 2016 & 2017 & 2018 & $\begin{array}{c}\text { 2019 upto } \\
\text { November 15 }\end{array}$ \\
\hline NUMBER OF CASES & 706 & 1636 & 2166 & 2199 & 2155 & 2146 & 2135 & 1947 \\
\hline
\end{tabular}

Reforms In Management Of Cases Related To Crime Against Women
- A Rape Crisis Cell should be set up. The Cell should be immediately notified when an FIR in relation to 
sexual assault is made. The Cell must provide legal assistance to the victim.

- All police stations should have CCTVs at the entrance and in the questioning room.

- A complainant should be able to file FIRs online.

- Police officers should be duty bound to assist victims of sexual offences irrespective of the crime's jurisdiction.

- Members of the public who help the victims should not be treated as wrong doers.

- The police should be trained to deal with sexual offences appropriately.

- Number of police personnel should be increased.

- Community policing should be developed by providing training to volunteers.

Delhi Police Crime Data Important Highlights Against Women

- 2,043 cases of rapes were registered in 2018 as compared to 2,059 cases in 2017

- $43 \%$ of the accused in rape cases were either friends or family friends, $16.25 \%$ were neighbours

- According to Delhi Police analysis, 43 per cent of the accused in rape cases were either friends or family friends, 16.25 per cent were neighbours, 12.04 per

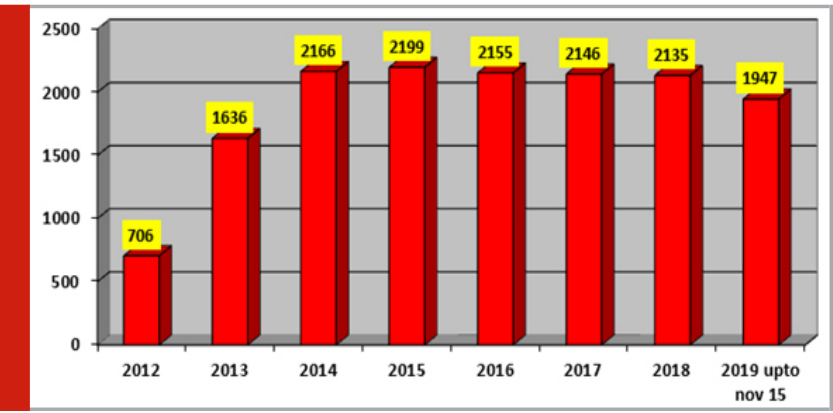

cent were relatives, 2.89 per cent were co-workers, 22.86 per cent were other known persons.

- A meagre 2.5 per cent of the accused were not known to the victim, police said, adding that this was a decline from the previous years.

- In 2017 and 2016, strangers comprised 3.36 and 3.57 per cent of those arrested for rape.

- As many as 2,290 arrests were made in rape cases last year as compared to 2,275 in 2017 and 2,072 in 2018.

- Police have requested the Delhi government for improving last mile connectivity and also requested the Social Welfare Department for initiating programmes for awareness and education in slums and places recording higher incidents of crime against women.

- Delhi Police has also requested the city government for installation of lights on dark stretches, including self-defence as part of school curriculum.

- As safety of women in the national capital continues to remain a cause of concern, police have laid emphasis on popularisation of 'Himmat Plus', creating gender sensitisation and mindset reformation as a part of 'Sashakti'. Identification of dark stretches and sharing information with civic agencies is also on the fore.

- $\quad$ Five women were raped and eight were molested everyday on an average in the national capital last year, Delhi Police spokes person said in press conference.

- According to Delhi Police data, 2,043 cases of rapes were registered last year as compared to 2,059 cases the year before that and 2,065 cases in 2016 .

- $\quad$ Last year, 3,175 cases of molestation were reported as compared to 3,275 cases the year before and 4,032 cases in 2016. In most of the rape cases, the accused were known to the victim, police said.

Table 3. Assault On Women With Intent To Outrage Her Modesty (354 IPC)

\begin{tabular}{|l|c|c|c|c|c|c|c|c|}
\hline YEARS & 2012 & 2013 & 2014 & 2015 & 2016 & 2017 & 2018 & $\begin{array}{c}2019 \text { upto } \\
\text { November 15 }\end{array}$ \\
\hline NUMBER OF CASES & 727 & 3515 & 4322 & 5367 & 4165 & 3422 & 3314 & 2616 \\
\hline
\end{tabular}

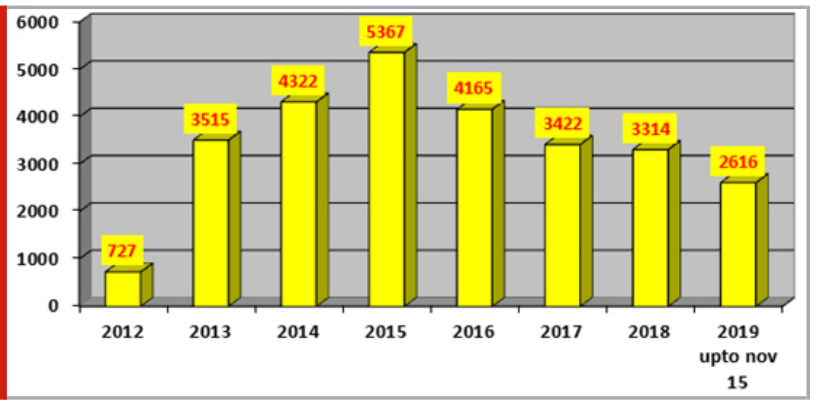

Here we can see that there is an increase in number of rape cases registered from year 2012 to 2015 and after that there is a slight decrease in the number of rape cases registered from year 2016 to 2019.
Here we can see that the number of assault cases registered has increased from year 2012 to 2015 and after that there is a slight decrease in number of assault cases registered from year 2016 to 2019.

Here we can see that the number of Insult to modesty cases registered has sharply increased from 2012 to 2015 whereas it has shapely decreased in numbers from year 2016 to 2019.

Here we can see that number of kidnapping of women cases registered has increased from year 2012 to 2015 and after that it has slightly decreased from year 2015 to 2017.In year 2018 it has slightly increased and in year 2019 it has come down once again. 
Table 4. Insult to the Modesty of Women (509 Ipc) 214

\begin{tabular}{|l|c|c|c|c|c|c|c|c|}
\hline YEARS & 2012 & 2013 & 2014 & 2015 & 2016 & 2017 & 2018 & $\begin{array}{c}2019 \text { upto } \\
\text { November 15 }\end{array}$ \\
\hline NUMBER OF CASES & 214 & 916 & 1361 & 1492 & 918 & 640 & 599 & 429 \\
\hline
\end{tabular}

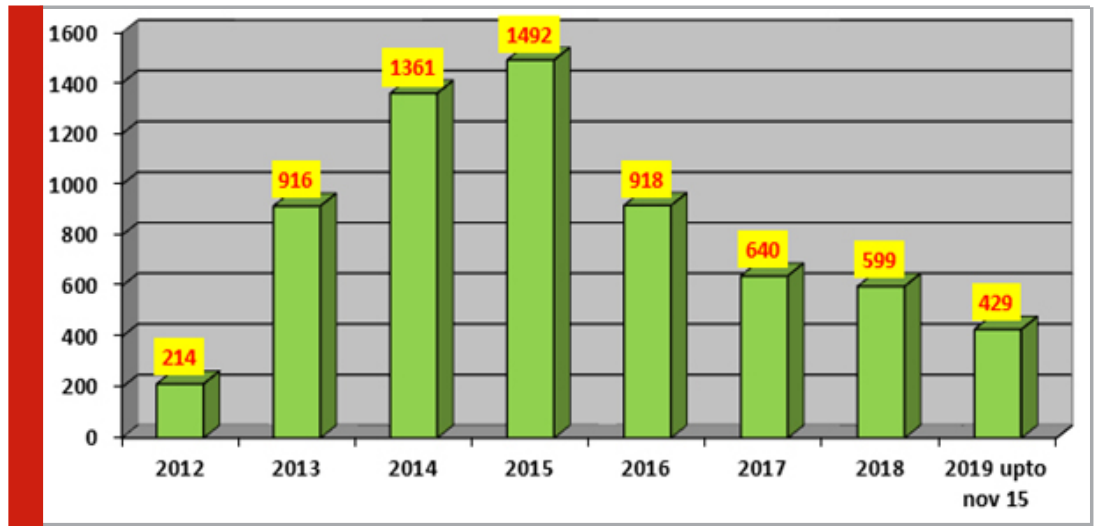

Table 5. Kidnapping Of Women (361 Ipc)

\begin{tabular}{|l|c|c|c|c|c|c|c|c|}
\hline YEARS & 2012 & 2013 & 2014 & 2015 & 2016 & 2017 & 2018 & $\begin{array}{c}\text { 2019 upto } \\
\text { November 15 }\end{array}$ \\
\hline NUMBER OF CASES & 2048 & 3286 & 3604 & 3738 & 3445 & 3439 & 3482 & 3104 \\
\hline
\end{tabular}

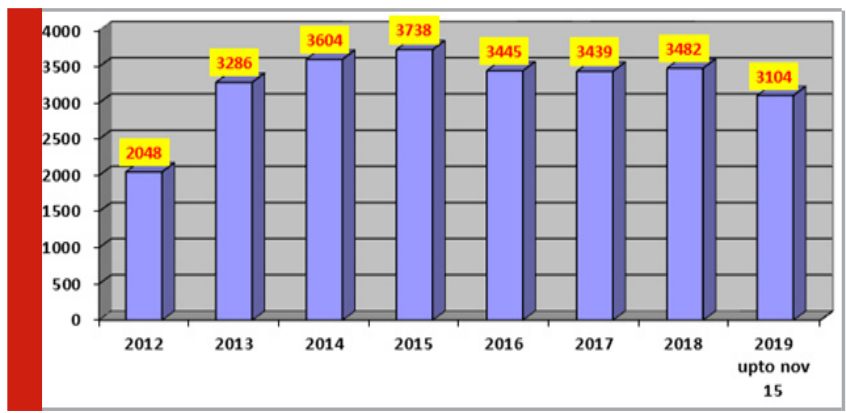

Table 6. Abduction of Women(362 IPC)

\begin{tabular}{|l|c|c|c|c|c|c|c|c|}
\hline YEARS & 2012 & 2013 & 2014 & 2015 & 2016 & 2017 & 2018 & $\begin{array}{c}2019 \text { upto } 1^{\text {th }} \\
\text { November }\end{array}$ \\
\hline NUMBER OF CASES & 162 & 323 & 423 & 556 & 444 & 322 & 262 & 170 \\
\hline
\end{tabular}

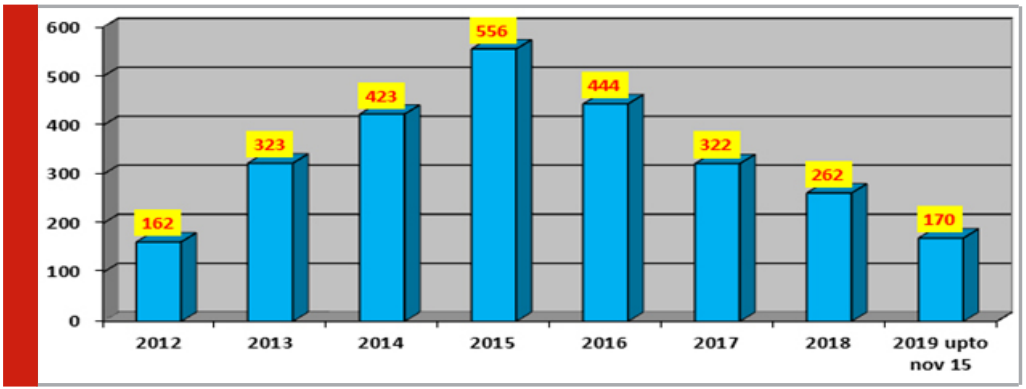


Here we can see that there is sharp increase in number of abduction cases from year 2012 to 2015 and after that the number of abduction cases have come down (decreased) from year 2016 to 2019.

Here we can see that the number of dowry death cases has increased from year 2012 to 2014. In year 2015 less dowry cases were registered whereas in year 2016 it again rose up and in year 2017 it again came down and it slightly increase in year 2018 and again it decreases in year 2019.

Here we can see that the number of dowry death cases has increased from year 2012 to 2014. In year 2015 less dowry cases were registered whereas in year 2016 it again rose up and in year 2017 it again came down and it slightly increase in year 2018 and again decrease in year 2019.

Table 7. 498-A/406 IPC (Cruelty By Husband And In Laws)

\begin{tabular}{|l|c|c|c|c|c|c|c|c|}
\hline YEARS & 2012 & 2013 & 2014 & 2015 & 2016 & 2017 & 2018 & $\begin{array}{c}2019 \text { upto } \\
15^{\text {th }} \text { Nov }\end{array}$ \\
\hline NUMBER OF CASES & 2046 & 3045 & 3194 & 3536 & 3877 & 2745 & 3416 & 3187 \\
\hline
\end{tabular}

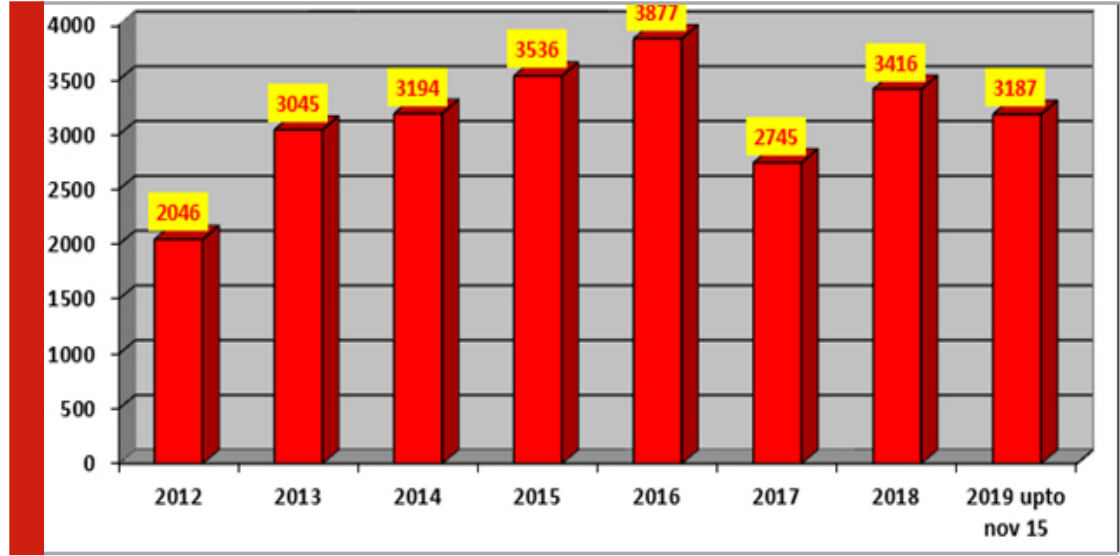

Table 8. Dowry Death (304B IPC)

\begin{tabular}{|l|c|c|c|c|c|c|c|c|}
\hline YEARS & 2012 & 2013 & 2014 & 2015 & 2016 & 2017 & 2018 & $\begin{array}{r}2019 \text { upto } \\
15^{\text {th }} \text { Nov }\end{array}$ \\
\hline NUMBER OF CASES & 134 & 144 & 153 & 122 & 162 & 120 & 153 & 106 \\
\hline
\end{tabular}

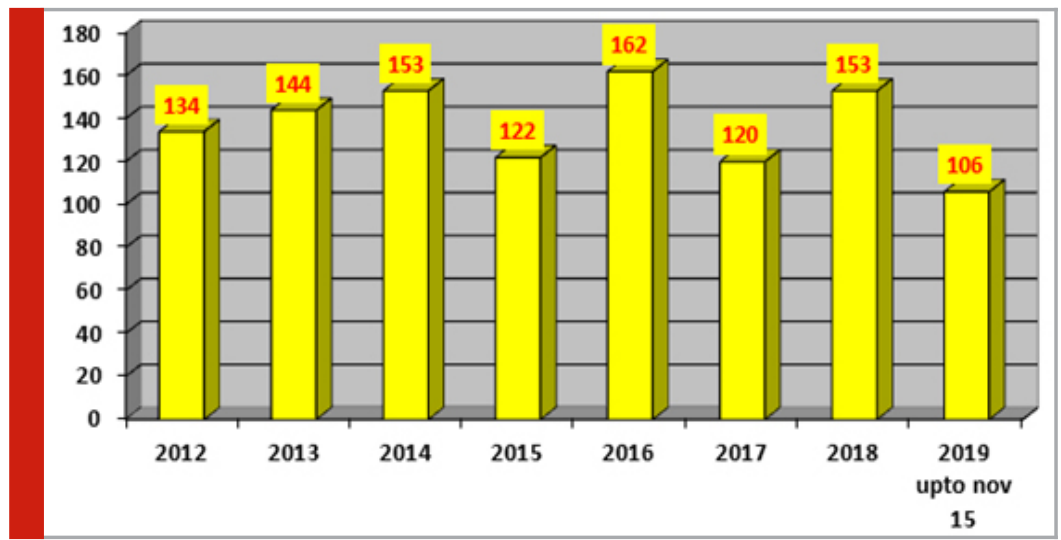

Here we can see that cases registered under the dowry prohibition act in year 2012 and 2013 remained the same where as it decreased in year 2014.In year 2015 it reached to its peak \&t in year 2016 to 2017 it has decreased slightly whereas from year 2018 to 2019 it has increased once again. 
Table 9. Dowry Prohibition ACT 1961

\begin{tabular}{|l|c|c|c|c|c|c|c|c|}
\hline YEARS & 2012 & 2013 & 2014 & 2015 & 2016 & 2017 & 2018 & $\begin{array}{r}2019 \text { upto } \\
15^{\text {th }} \text { Nov }\end{array}$ \\
\hline NUMBER OF CASES & 15 & 15 & 13 & 20 & 18 & 11 & 15 & 16 \\
\hline
\end{tabular}

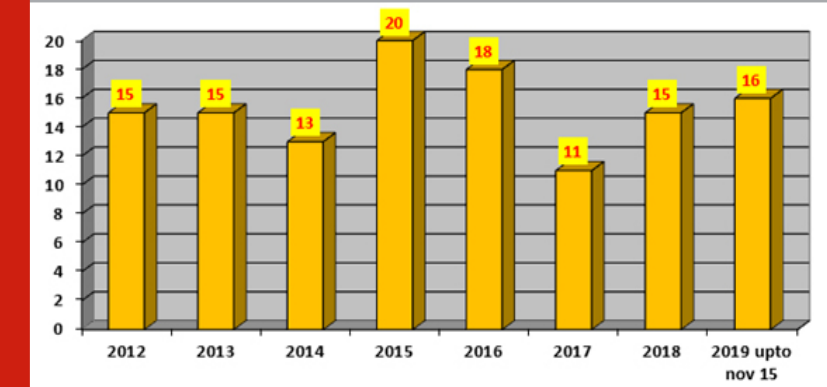

Analysis and Findings Based On The Study Of Table And Graph: Based on the study of these graphs it has come to light that maximum numbers of cases where registered in year 2015 and thus crime rates where highest and on its peak and from 2016 onwards the number of cases came down and again rose up. Thus we can see slight increase and decrease in number of different crime cases committed against the women.

Disha Bill: Andhra Pradesh New Law On Rape: The Andhra Pradesh Legislative Assembly has passed the Andhra Pradesh Disha Bill, 2019 (Andhra Pradesh Criminal Law (Amendment) Act 2019). The bill provides for awarding death sentence for offences of rape and gang rape and expediting trials of such cases to within 21 days. The Act envisages the completion of investigation in seven days and trial in 14 working days, where there is adequate conclusive evidence, and reducing the total judgment time to 21 days from the existing four months. The AP Disha Act also prescribes life imprisonment for other sexual offences against children and includes Section $354 \mathrm{~F}$ and $354 \mathrm{G}$ in IPC

Recommendations: It is suggested that further studies can be conducted on the basis of the findings of this study. More newspapers, especially local newspapers should be examined to reveal different patterns of reporting of crime news. The findings obtained could be compared with the present findings. Studies of the public perception of the phenomenon of crime and the criminal justice system should also be conducted to explore the effect of the media on the audience. For this type of study, Doris Appel Graber's study may help determine the degree to which the public relies on crime news to form their opinion about crime issues and if there is fear of crime among the public that is caused by the media.

\section{DISCUSSION}

Rape coverage in the media has many effects in society. It often shapes the way in which people think about rape, as well as how they receive rape victims, rapists and those accused of rape. Thus, the media coverage of crime against women especially rape is very important area of interest for media anthropologists. The two aspects of Delhi gang rape case were covered: optimism and struggle. The optimism, on one hand, and the struggle for survival, on the other hand, appeared to be the most common themes related to the victim's portrayal. It is due to wide-spread coverage by the media that Delhi gang rape case received attention both nationally and internationally. It also forced the law making bodies to take the crimes against women especially rape more seriously. Thus, media activation played a very important role in generating a public opinion and a nation-wide protest. Due to the rare nature of the Delhi gang rape case, it has been widely covered in Indian print media. Repeatedly in the portrayal, metropolitan cities especially Delhi have been described as unsafe for women. It has been mentioned that there is insecurity among the women about their safety.

\section{CONCLUSION}

It can be concluded that media needs to be more sensitive towards coverage of crime against women and general public needs to be more vocal and aware to deal with these cases in more effective manner. Due to the rare nature of the Delhi gang rape case, it has been widely covered in Indian print media. Repeatedly in the portrayal, metropolitan cities especially Delhi have been described as unsafe for women. It has been mentioned that there is insecurity among the women about their safety. It can be concluded that media needs to be more sensitive towards coverage of crime against women and general public needs to be more vocal and aware to deal with these cases in more effective manner.

\section{REFERENCES}

Arulselvan S. Role of Media in Making Public Policy on India's Criminal Justice System: A Study of News Reporting on Actor Salman Khan's Acquittal in A Murder Case. Global Media Journal. 2016, 14:26

C. S. H. N. Murthy, Challa Ramakrishna and Srinivas R. Melkote, (2010). Journal Media and Communication Studies Vol. 2(2) pp. 039-053

Chandan Mukherjee, Preet Rustagi and N. Krishnaji (2001), "Crimes against Women in India: Analysis of Official Statistics" Economic and Political Weekly, Vol. 36, No. 43 pp. 4070-4080

Jason Burke, The problem with crime against women in Delhi, https://www.theguardian.com/ 
commentisfree/2011/feb/22/problem-crime-againstwomen-delhi

Joseph, Ammu, "When violence is not news", India together, New Delhi, (2004). Jason Burke (2011), The problem with crime against women in Delhi.

Kaveri Devi Mishra, Sridhar Krishnaswami (2014) Citizens Journalism in India: a Case Study of Delhi, Journal of Education \& Social Policy Vol. 1 No. 1.

Kriti Singh (2016) A Small Study On Impact Of Crime Against Women News Stories On Indian Urban, Imperial Journal of Interdisciplinary Research, Vol-2, Issue-3
Patowary, H. (2014). Portrayal of Women in Indian Mass Media: An Investigation.Journal of Education \& Social Policy, Volume 1, Issue 1.

Radha and P. Govindaraju, Reception of news reports on violence against women by youth in Tamilnadu, International Journal of Advanced Scientific Research and Management, Vol. 1 Issue 11, Nov 2016.

Reetinder Kaur, Representation of Crime against Women in Print Media: A Case Study of Delhi Gang Rape, Anthropol 2013, 2:1 